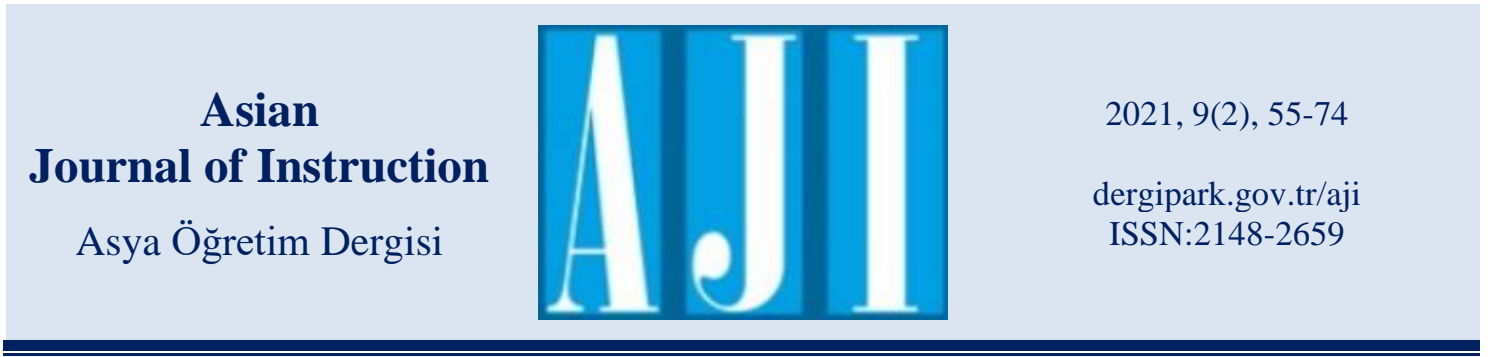

Geliş Tarihi: 23/09/2021

Kabul Tarihi: 14/12/2021

Yayınlanma Tarihi: 31/12/2021

\title{
Ortaokul Matematik Öğretmenlerinin Eleştirel Düşünme Eğilim ve Uygulama Algıları Arasındaki İlişki*
}

\author{
Ersin Tunçer ${ }^{1}$, Ahmet Sapanci ${ }^{2}$
}

Tunçer, E., \& Sapancı, A. (2021). Ortaokul matematik öğretmenlerinin eleştirel düşünme eğilim ve uygulama algıları arasındaki ilişki. Asian Journal of Instruction, 9(2), 55-74. https://doi.org/10.47215/aji.1000040

\section{$\ddot{\mathbf{O} z}$}

$\mathrm{Bu}$ çalışmanın temel amacı ortaokul matematik öğretmenlerinin eleştirel düşünme eğilim ve uygulama algıları arasındaki ilişkiyi ortaya koymaktır. Araştırmanın örneklemini, Düzce, Karabük, Çorum ve Kastamonu illerinde görev yapan 852 ortaokul matematik öğretmeni arasından uygun (kolayda) örneklem yöntemi ile seçilen 381 kişi oluşturmaktadır. Araştırmada veri toplama aracı olarak Eleştirel Düşünme Eğilim Ölçeği ve Eleştirel Düşünme Öğretimi Uygulama Düzeyi Ölçeği kullanılmıştır. Araştırmadan elde edilen veriler SPSS 25.00 programında analiz edilmiştir. Verilerin analizinde bağımsız örneklemler $t$-testi, tek yönlü varyans analizi, Pearson korelasyon analizi ve çoklu doğrusal regresyon analizi kullanılmıştır. Araştırma sonucunda cinsiyete göre, eleştirel düşünme öğretimi uygulamalarının öğretim ortamı alt boyutunda kadın öğretmenler lehine anlamlı bir farklılık olduğu bulunmuştur. Hizmet içi eğitim alma durumuna göre, eleştirel düşünme eğilimi ve uygulama algıları düzeylerinin her ikisinde de, hizmet içi eğitim alan grubun lehine, anlamlı bir farklılık olduğu bulunmuştur. Kıdeme göre ise eleştirel düşünme eğiliminin üstbiliş alt boyutunda, eleştirel düşünme uygulama algılarının ise öğretmen nitelikleri alt boyutunda kıdemi 16 yıl ve üstü olan grubun lehine anlamlı bir fark bulunmuştur. Matematik öğretmenlerinin eleştirel düşünme eğilim ve uygulama algıları arasında pozitif anlamlı bir ilişki olduğu, eleştirel düşünme eğilim ölçeğinin üstbiliş, azim ve sabır ile açık fikirlilik alt boyutlarının eleştirel düşünme öğretimi uygulamalarının anlamlı yordayıcıları olduğu bulunmuştur.

Anahtar Kelimeler: Eleştirel düşünme eğilimi, eleştirel düşünme uygulamaları, ortaokul matematik öğretmenleri

\section{The Relationship between Critical Thinking Tendency and Practical Perceptions of Middle School Mathematics Teachers}

\begin{abstract}
The purpose of this study is to determine the relationship between critical thinking tendencies and critical thinking teaching practices of middle-school mathematics teachers. The study sample consists of 381 secondary school mathematics teachers selected with convenience sampling techniques among the non-random sampling methods among 852 secondary school mathematics teachers working in Düzce, Karabük, Çorum, and Kastamonu provinces. Critical Thinking Tendency and Critical Thinking Teaching Practice Level scales were used as data collection tools

\footnotetext{
* Bu çalışma ikinci yazarın danışmanlığında, birinci yazar tarafindan, Düzce Üniversitesi Sosyal Bilimler Enstitüsünde hazırlanan “Ortaokul Matematik Öğretmenlerinin Eleştirel Düşünme Eğilim ve Uygulama Algıları Arasındaki İlişki” başlıklı yüksek lisans tez çalışmasından üretilmiştir.

${ }^{1}$ Bilim Uzman1, Gümüşova Borsa İstanbul AİHL, https://orcid.org/0000-0002-3652-1567, ersntuncer78@ gmail.com

${ }^{2}$ Dr. Öğr. Üyesi, Düzce Üniversitesi Eğitim Fakültesi, https://orcid.org/0000-0003-4688-6890, ahmetsapanci@duzce.edu.tr
} 
in research. The data obtained from the research were analyzed in SPSS 25.00. Independent samples $t$-test, one way variance analysis, Pearson correlation analysis and multiple linear regression analysis were used to analyze the data. According to the results of the research, it was found that there was a significant difference in favor of female teachers in the sub-dimension of critical thinking teaching practices according to gender. It was found that there was a significant difference in favor of the group that received in-service training in both the levels of critical thinking disposition and perceptions of practice, according to the status of receiving in-service training. According to seniority, a significant difference was found in favor of the group with 16 years or more seniority in the metacognition sub-dimension of critical thinking disposition and in the teacher qualifications sub-dimension of critical thinking practice perceptions. It was found that there was a positive and significant relationship between mathematics teachers' critical thinking disposition and perceptions of practice, and the metacognition, perseverance and patience and open-mindedness sub-dimensions of the critical thinking disposition scale were significant predictors of critical thinking teaching practices.

Keywords: Critical thinking practices, critical thinking tendency, middle school mathematics teachers

\section{Giriş}

Tüm dünyada hızla gelişen bilim ve teknoloji, kişilerden ve kurumlardan beklentiyi farklı boyutlara taşımıştır. Dünyanın içinde bulunduğu şartlar ve zaman içinde yaşanan değişimler kişilerden beklenen becerileri de değiştirmektedir. Bu beklentiler eğitim kurumlarına olan bakışı değiştirmiş̧ir. Bu değişime bağlı olarak eğitim sisteminde artık önemli olan bilginin aktarılması değil, öğrencilerin bilgiyi anlamlandırabilmeleri, önemli ve önemsiz olanı ayırt edebilmeleridir (Harari, 2018). Farklı eğitim sistemleri, öğrencilerin sürekli değiş̧en ve giderek karmaşıklaşan bir dünyaya katılmak için gerekli becerileri edinmelerinin önemini vurgulamıştır (Pellegrino \& Hilton, 2012). Bu nedenle düşünme becerileri dünyada ve eğitim programlarında önemli yer tutmaktadır. Günümüzde sahip olunması gereken, 21. yüzyıl becerileri olarak adlandırılan becerilere bakıldığında, eleştirel düşünme becerisinin bu beceriler arasında yer aldığ görülmektedir (Dünya Ekonomik Forumu, 2018).

Eleştirel düşünme, problem çözmede kullanılan zihinsel süreç, strateji ve yöntemler bütünüdür (Sternberg,1999). Eleştirel düşünmede, kişi sunulan bilgileri anlamlandırarak neyin doğru veya neyin yanlış olduğuna karar vermektedir (Ennis, 1985). Nosich'e (2012) göre eleştirel düşünme, sormak, irdelemek, soruları mantıksal bir zemine oturtarak çözüme kavuşturmayı ve neticelerine inanmay1 ele alır.

Kişilerin eleştirel düşünmeye sahip olabilmeleri için bazı becerileri kazanmış olmaları gerekmektedir. Eleştirel düşünme becerilerine sahip olmak kişilere düşüncelerini değerlendirip altta yatan sebeplerin farkına varmalarına katkıda bulunur. Problem karşısında çözüm yolları üzerine düşünmelerini sağlarken kendi fikirlerini de yapılandırmalarına katkıda bulunur (Hayırsever \& Oğuz, 2017). Seferoğlu ve Akbıyık (2006) eleştirel düşünme becerilerini; fikirleri analiz etme, dile getirilmemiş düşünceleri fark etme, kalıplaşmış düşünceleri fark etme, ortaya konulacak düşüncelerin farklı ifade biçimlerini araştırma olarak belirtmişlerdir.

Bir beceriye sahip olmak onu uygulamak için tek başına yeterli olmaz. Beceriyi uygulamaya dönüştürmeye istekli olmak da gerekir. Kişinin iyi düşünebildiğinin göstergesi araştırma yapmaya, bilginin kesinliğini aramaya ve eleştirel düşünmeye olan eğilimleridir (Seferoğlu \& Akbıyık, 2006). Kişilerin eğilimleri, onların davranışlarına ve sahip oldukları davranışları kullanmalarına yön vermektedir (Tishman, Jay \& Perkins, 1992). Eleştirel düşünme eğilimi, eleştirel düşünme becerisi için gerekli olup, kişinin herhangi bir konu hakkında karar vermesini sağlayan dairesel bir süreçtir (Facione \& Facione, 1996). Bir iddianın veya problemin gerçek ifadesini araştırma, iddia ile ilgili nedenler arama, bilgi için güvenilir kaynakları bulmaya çalışma, bütüncül bakış açısıyla olaya yaklaşma, ana problemden sapmama, alternatifler üretme, açık fikirli olma, sorunun çözümüne ilişkin yeterli sebep bulunduğunda karar alabilecek sorumluluğu gösterme gibi özellikler eleştirel düşünme eğiliminin temel göstergeleridir (Ennis, 1985: 68). 
Eleştirel düşünme becerilerine ve eğilimine sahip öğretmenler eleştirel düşünmenin öğretilmesi noktasında da yeterli donanıma sahip olmalıdırlar. Eleştirel düşünme becerisinin öğretiminde öncelikle eleştirel düşünme kavramı çok iyi tanımlanmalı ve öğrencilere eleştirel düşünmenin gerekliliği vurgulanmalıdır (Şahinel, 2007: 52). Çünkü yeterince ifade edilememiş, açıklığa kavuşturulmamıș eleştirel düşünme kavramı, öğrencilerin gözünde sıradan bir öğretim veya etkinlikten öteye geçemeyecektir. Hirose'ye (1992) göre öğrenciler bir gerçeği ezberlemenin ötesine geçmeli ve bu gerçeği belirli bir düşünce alanına uyarlamaları için teşvik edilmelidir.

Eleştirel düşünme becerileri kazandırılması için öğretmenlerin öğrenme ortamlarını buna göre düzenlemeleri, öğrencilere belirli bilgileri aktaran kişi rolünden çıkarak esnek düşünmeyi ve sorgulamayı teşvik eden kişi pozisyonuna geçmeleri önemlidir. Ayrıca öğrencilerin daha çok açık uçlu sorular sormalarının, problemleri düşünme, analiz etme ve kavramsallaştırmalarının teşvik edilmesi eleştirel düşünme becerilerinin kazandırılması sürecinde önemlidir.

Matematik derslerinde eleştirel düşünme etkinlikleri öğrencileri temel becerilerin etkilerine göre daha başarılı kılacaktır. Çünkü üst düzey düşünme becerilerinin öğrencilere erken yaşlarda kazandırılması temel işlem basamaklarını öğrenme noktasında öğrencilerin motivasyonunu artıracaktır (Wenglinsky, 2004). Bu nedenle sınıflarında eleştirel düşünme becerisini kazandırmak isteyen matematik öğretmenlerinin amacı, öğrencilerini bilgi alıcıları olarak değil bilgi kullanıcıları olarak düşünmek olmalıdır. Öğrencileri aktif olarak bilgi araştırmasına ve elde edilen bilginin uygulanmasına dahil eden matematik öğrenme ortamlarında öğrencilerin eleştirel düşünme becerileri gelişecek ve böylece öğrenciler üst düzey düşünme becerilerini kazanmış olacaktır. Ayrıca matematik derslerinde süreç boyunca öğrencileri teşvik ederek ve düşünme davranışlarını modelleyerek eleştirel düşünme becerileri geliştirilebilir (Peter, 2012).

Eleştirel düşünme üzerine yapılan çalışmalar incelendiğinde yurt dışındaki çalışmaların özellikle eleştirel düşünme becerisinin etkileri üzerine yoğunlaştı̆̆ görülmektedir (Adams, Whitlow, Stover \& Johnson, 1999; Annable, 2006; Aoki, 2018; Reed \& Kromrey, 2001; Yang, 2012). Bununla beraber Türkiye'de yapılan çalışmaların ağılıklı olarak öğrenci ve öğretmen adayları üzerinde yapıldığı görülmektedir (Akınoğlu, 2001; Eldeleklioğlu \& Özkılıç, 2008; Ersoy \& Başer, 2011; Ertaş, 2012; Erüs, 2007; Kanik, 2010; Kurnaz, 2007; Özüberk, 2002; Aslan, 2010; Schreglmann, 2012; Şahinel, 2001). Yapılan çalışmaların ağırlıklı olarak öğrenci ve öğretmen adaylarında eleştirel düşünme becerisini geliştirici etkinlik ve uygulamaların etkilerini belirlemeye yönelik olduğu görülmüştür. Literatürde eleştirel düşünme eğilimi üzerine yapılan çalışmalara bakıldığında (Bayram, 2015; Beşoluk \& Önder, 2010; Demirtaş, 2019; Gündüz, 2017; Güner, 2015; Hayırsever \& Oğuz, 2017; Karalı, 2012; Küçük, 2007; Schreglmann, 2011) ağırlıklı olarak öğretmen adayları üzerine çalışmalar yapıldığ görülmektedir. Öğretmen örnekleminde yapılan çalışmalarda ise, eleştirel düşünme becerilerinin incelendiği çeşitli çalışmalar (Aşık, 2018; Aslan, 2019; Özsevgeç \& Altun, 2015; Söğüt, 2009) bulunmaktadır. Ayrıca öğretmenlerde eleştirel düşünme eğilimlerine yönelik çalışmalar (Akbulut, 2019; Erden, 2009; Kandemir, 2017; Korkmaz, 2009; Kural, 2018; Sofuoğlu, 2019; Özden, 2019) ve sınıf içi uygulamalarına yönelik (Gelen, 1999; Göbel, 2013; Melek, 2011; Özyurt \& Bezirgan, 2019; Yağc1, 2008) araştırmalar olduğu görülmüştür. Diğer taraftan öğretmenlerin eleştirel düşünme eğilimleri ile eleştirel düşünmeyi geliştirici sınıf içi uygulamalar arasındaki ilişkiyi belirlemeye yönelik (Şahin, 2014; Şengül \& Üstündağ, 2009) yapılan çalışmaların sayısı oldukça az ve matematik dışı branşlarda gerçekleştirilmiş olduğu görülmektedir. Dolayısıyla Türkiye' de yapılan çalışmalarda matematik öğretmenlerinin eleştirel düşünme eğilimleri ile bunların eleştirel düşünmeyi geliştirici öğretim uygulamalarına olan etkilerini inceleyen bir araştırmaya rastlanmamaktadır. Eleştirel düşünme becerileri 2005 yılından itibaren öğretim programlarının hedefleri arasında yer almaktadır. Programın ön gördüğü bu hedeflere ulaşılma düzeylerinin ortaya konulması, programın eğitim alanında yararlı bir şekilde uygulanabilirliğini görmek açısından bu çalışma önem taşımaktadır. Diğer taraftan program geliştirme çalışmalarının özünde hazırlanan programlardan sürekli geri dönütler 
alınması önemli görülmüştür (Bilen, 2006; Büyükkaragöz \& Çivi, 1999; Demirel, 2015; Ertürk, 2016; Sönmez, 2015; Varış, 1997). Bu sebeple öğretim programının çıktılarının değerlendirilebilmesi, programın işleyen veya aksayan birimlerinin tespit edilip gerekli düzeltmelerin yapılabilmesi için araştırma önem taşımaktadır. Bu araştırmanın temel amacı, ortaokul matematik öğretmenlerinin eleștirel düșünme eğilim ve uygulama algıları arasındaki ilişkileri belirleyerek gerek sınıf içi öğretim uygulamalarına ve gerekse ilgili literatürü katkıda bulunmaktır. $\mathrm{Bu}$ amaç doğrultusunda aşağıdaki sorulara yanıt aranmıştır:

1. Ortaokul matematik öğretmenlerinin eleştirel düşünme eğilim algıları hangi düzeydedir?

2. Ortaokul matematik öğretmenlerinin eleştirel düşünme eğilim alg1 düzeyleri

a) Cinsiyete göre

b) Kideme göre

c) Eleştirel düşünme ile ilgili eğitim alıp almama durumuna göre farklılık göstermekte midir?

3. Ortaokul matematik öğretmenlerinin eleştirel düşünme öğretimi uygulama algıları hangi düzeydedir?

4. Ortaokul matematik öğretmenlerinin eleştirel düşünmeyi geliştirici uygulama alg1 düzeyleri

a) Cinsiyete göre

b) Kideme göre

c) Eleştirel düşünme ile ilgili eğitim alıp almama durumuna göre farklılık göstermekte midir?

5. Ortaokul matematik öğretmenlerinin eleştirel düşünme eğilimleri ile eleştirel düşünme öğretimi uygulama düzeyleri arasında anlamlı bir ilişki var mıdır?

6. Ortaokul matematik öğretmenlerinin eleştirel düşünme eğilim algı düzeyleri, eleştirel düşünme öğretimi uygulama algı düzeylerini yordamakta mıdır?

\section{Yöntem}

Araştırmanın bu bölümünde, araştırma modeline, evren ve örneklem bilgilerine, veri toplama araçları hakkında bilgilere, verilerin elde dilmesine ve verilerin analizine yer verilmiştir.

\subsection{Araştırma Modeli}

Bu çalışmada, ortaokul matematik öğretmenlerinin eleştirel düşünme eğilim ve eleştirel düşünme öğretimi uygulama alg1 düzeyleri arasındaki ilişkiyi incelenmek amacıyla nicel araştırma yöntemlerinden ilişkisel tarama modeli kullanılmıştır. İlişkisel tarama modeli; iki ya da daha fazla sayıdaki değişken arasında, birlikte değişimin varlığını ve/veya derecesini belirlemeyi amaçlayan bir araştırma modelidir (Fraenkel \& Wallen, 2006; Karasar, 2012).

\subsection{Evren ve Örneklem}

$\mathrm{Bu}$ araştırmanın evrenini 2019-2020 eğitim öğretim yılı 1. döneminde Düzce, Karabük, Kastamonu ve Çorum illerinde görev yapan ortaokul matematik öğretmenleri, örneklem ise bu öğretmenler arasından belirlenen 381 kişiden oluşmuştur. Araştırma örneklemini belirlemede uygun örnekleme yöntemi (convenience sampling) kullanılmıştır. Uygun örnekleme, zaman, para ve işgücü kaybını önlemeyi amaçlar (Büyüköztürk, Kılıç Çakmak, Akgün, Karadeniz \& Demirel, 2012) ve araştırmacı için "uygun" olan yanıtlayıcıların kullanılmasını içerir (Galloway, 2005). Örneklemin bağımsız değişkenlere göre dağılımları Tablo 1'de verilmiştir. 
Tablo 1. Araştırma Örnekleminin Değişkenlere Göre Dağılımı

\begin{tabular}{|c|c|c|c|}
\hline \multicolumn{2}{|c|}{ Değișkenler } & $\mathbf{N}$ & $\%$ \\
\hline \multirow{2}{*}{ Cinsiyet } & Kadın & 246 & 64.6 \\
\hline & Erkek & 135 & 35.4 \\
\hline \multirow{4}{*}{ Kidem } & $1-5$ yil & 110 & 28.9 \\
\hline & 6-10 yil & 87 & 22.8 \\
\hline & $11-15$ y1l & 114 & 29.9 \\
\hline & 16 y1l ve üstü & 70 & 18.4 \\
\hline \multirow{2}{*}{$\begin{array}{l}\text { Eleştirel Düşünme ile İlgili } \\
\text { Eğitim Alma Durumu }\end{array}$} & Evet & 28 & 7.3 \\
\hline & Hayır & 353 & 92.7 \\
\hline \multicolumn{2}{|c|}{ Toplam } & 381 & 100 \\
\hline
\end{tabular}

Tablo 1'e göre araştırma örnekleminin \%64.6'sını (N=246) kadın, \%35.4'ünü (N=135) erkek öğretmenler, \%28.9'unu (N=110) 1-5 y1l k1deme, \%22.8'ini (N=87) 6-10 y1l kıdeme, \%29.9'unu ( $\mathrm{N}=114)$ 11-15 y1l kıdeme ve \%18.4'ünü $(\mathrm{N}=70) 16$ yıl ve üstü kıdeme sahip öğretmenler ve \%7.3'ünü $(\mathrm{N}=28)$ eleştirel düşünme ile ilgili eğitim almış, \% 92.7'sini ( $\mathrm{N}=353)$ eğitim almamış öğretmenler oluşturmaktadır.

\subsection{Veri Toplama Araçları}

Bu çalışmada kullanılan veri toplama araçları üç bölümden oluşmaktadır. Birinci bölümde araştırmacı tarafından hazırlanan Kişisel Bilgiler Formu, ikinci bölümde Semerci (2016) tarafından geliştirilen Eleştirel Düşünme Eğilimi Ölçeği ve son bölümde Göbel (2013) tarafından geliştirilen Eleştirel Düşünme Öğretimi Uygulama Ölçeği yer almaktadır.

\subsubsection{Eleştirel Düşünme Eğilimi Ölçeği}

Eleştirel Düşünme Eğilimi Ölçeği Semerci (2016) tarafından öğretmen ve öğretmen adaylarının eleştirel düşünme eğilim düzeylerini belirlemek amacı ile geliştirilmiştir. 49 madde ve 5 alt boyuttan oluşan ölçek 5'li likert tipindedir (Tamamen katılıyorum $=5$ puan, Hiç katılmıyorum $=$ 1 puan). Ölçeğin Cronbach alfa güvenirlik katsayıları ölçeğin tümü için .96, alt boyutlarda ise üstbiliş .87 , esneklik .88 , sistematiklik .90 , azim ve sabır .89 ve açık fikirlilik .73 olarak bulunmuştur.

\subsubsection{Eleştirel Düşünme Öğretimi Uygulama Ölçeği}

Eleştirel Düşünme Öğretimi Uygulama Ölçeği, Göbel (2013) tarafından geliştirilen, öğretmenlerin eleştirel düşünmeyi geliştirici uygulamalara derslerinde ne derece yer verdiklerini belirlemeyi amaçlayan bir ölçme aracıdır. 15 madde ile uygulanan ölçek, 4 alt boyuttan oluşan 5'li likert tipindedir (Her zaman $=5$, Hiçbir zaman $=1$ ). Ölçeğin Cronbach alfa güvenirlik katsayıları ölçeğin tümü için .89 , alt boyutlarda ise öğretim ortamı .92, öğretmen nitelikleri .74, sinif atmosferi .73 ve kendini ifade etme .70 olarak bulunmuştur.

\subsection{Verilerin Analizi}

Elde edilen verilerin analizi bilgisayar ortamında SPSS 25.00 programı ile gerçekleştirilmiştir. Veriler normal dağılım gösterdiği için verilerin analizinde parametrik testler kullanılmıştır. Verilerin analizi yapılırken gruplar arasındaki farklılıkların belirlenmesinde için bağımsız gruplar $t$-testi ve tek yönlü ANOVA kullanılmıştır. ANOVA'da ortaya çıkan farklılıkların kaynağını belirlemek için çoklu karşılaştırma testleri (Post Hoc) uygulanmıştır. Çoklu karşılaştırma testlerinde varyansların homojen dağıldığı durumlar için Scheffe testi, varyansların homojen dağılmadığı durumlar için Tamhane's T2 testi uygulanmıştır. Değişkenler arası ilişki analizlerinde ise Pearson korelasyonu ve çoklu doğrusal regresyon kullanılmıştır. 


\subsection{Etik Kurul İzin}

Yapılan bu çalışmada "Yükseköğretim Kurumları Bilimsel Araştırma ve Yayın Etiği Yönergesi" kapsamında uyulması belirtilen tüm kurallara uyulmuştur. Bu çalışma için etik kurul izni Düzce Üniversitesi Bilimsel Araştırma ve Yayın Etik Kurulu'nun 16/05/2019 tarihli ve 2019/46 numaralı kararı ile alınmıştır.

\section{Bulgular}

Araştırmanın bu bölümünde veri toplama araçlarından elde edilen verilerin analiz sonuçlarına yer verilmiştir. Öncelikle katılımcıların eleştirel düşünme düzeyleri ölçek toplam puanı ve alt boyutlarına göre ayrı ayrı verilmiş daha sonra gruplar arası farklılıklar ve değişkenler arası ilişkilere yönelik bulgular verilmiştir.

Araştırmanın birinci alt problemi kapsamında ortaokul matematik öğretmenlerinin eleştirel düşünme eğilim algılarının düzeyi incelenmiş ve elde edilen bulgular Tablo 2'de sunulmuştur.

Tablo 2. Eleştirel Düşünme Eğilim Ölçeğinin Alt Boyutlarına Ait Betimsel İstatistikler

\begin{tabular}{lccccc}
\hline Alt Boyutlar & $\mathbf{N}$ & Min & Max & $\overline{\mathbf{X}}$ & Ss \\
\hline Üstbiliş & 381 & 3.21 & 5.00 & 4.35 & 0.41 \\
Esneklik & 381 & 2.27 & 5.00 & 4.31 & 0.48 \\
Sistematiklik & 381 & 2.54 & 5.00 & 4.31 & 0.47 \\
Azim Sabır & 381 & 2.75 & 5.00 & 4.28 & 0.55 \\
Açı Fikirlilik & 381 & 2.33 & 5.00 & 4.26 & 0.59 \\
Toplam & 381 & 3.20 & 5.00 & 4.31 & 0.42 \\
\hline
\end{tabular}

Tablo 2'de sunulan bulgulara göre, öğretmenlerinin eleştirel düşünme eğilimi toplam puan1 ortalamalarının ölçeğin tümü için 4.31 olduğu görülmektedir. Bu bulguya göre öğretmenlerin eleştirel düşünme eğilimi düzeylerinin çok yüksek düzeyde olduğu söylenebilir. Ayrıca alt boyutlarda da eleştirel düşünme eğilimi düzeylerinin çok yüksek olduğu görülmektedir.

Araştırmanın birinci alt problemi kapsamında ortaokul matematik öğretmenlerinin eleştirel düşünme eğilim algılarındaki farklılaşma durumu cinsiyet, kıdem ve eleştirel düşünme ile ilgili eğitim alma durumlarına göre incelenmiştir. Cinsiyete göre farklılaşma durumuna ilişkin bulgular Tablo 3'te verilmiştir.

Tablo 3. Cinsiyete Göre Ortaokul Matematik Öğretmenlerinin Eleştirel Düşünme Eğilimlerindeki Farklılaşmaya İlişkin Bağımsız Gruplar $t$-testi Sonuçları

\begin{tabular}{|c|c|c|c|c|c|c|c|}
\hline Alt Boyutlar & Cinsiyet & $\mathbf{N}$ & $\overline{\mathbf{X}}$ & Ss & $t$ & Sd & $p$ \\
\hline \multirow{2}{*}{ Üstbiliş̧ } & Kadın & 246 & 4,34 & \multirow{2}{*}{0,42} & \multirow{2}{*}{$-0,820$} & \multirow{2}{*}{379} & \multirow{2}{*}{.413} \\
\hline & Erkek & 135 & 4,37 & & & & \\
\hline \multirow{2}{*}{ Esneklik } & Kadın & 246 & 4,33 & \multirow{2}{*}{0,45} & \multirow{2}{*}{0,751} & \multirow{2}{*}{379} & \multirow{2}{*}{.453} \\
\hline & Erkek & 135 & 4,29 & & & & \\
\hline \multirow{2}{*}{ Sistematiklik } & Kadın & 246 & 4,29 & \multirow{2}{*}{0,48} & \multirow{2}{*}{$-0,700$} & \multirow{2}{*}{379} & \multirow{2}{*}{.485} \\
\hline & Erkek & 135 & 4,33 & & & & \\
\hline \multirow{2}{*}{ Azim Sabır } & Kadın & 246 & 4,27 & \multirow{2}{*}{0,54} & \multirow{2}{*}{$-0,478$} & \multirow{2}{*}{379} & \multirow{2}{*}{.633} \\
\hline & Erkek & 135 & 4,30 & & & & \\
\hline \multirow{2}{*}{ Açık Fikirlilik } & Kadın & 246 & 4,24 & \multirow{2}{*}{0,50} & \multirow{2}{*}{$-1,086$} & \multirow{2}{*}{335.63} & \multirow{2}{*}{.278} \\
\hline & Erkek & 135 & 4,30 & & & & \\
\hline \multirow{2}{*}{ Toplam } & Kadın & 246 & 4,31 & \multirow{2}{*}{0,42} & \multirow{2}{*}{$-0,435$} & \multirow{2}{*}{379} & \multirow{2}{*}{.664} \\
\hline & Erkek & 135 & 4,33 & & & & \\
\hline
\end{tabular}


Tablo 3'te sunulan bulgular incelendiğinde, cinsiyete göre ortaokul matematik öğretmenlerinin eleştirel düşünme eğilim algılarında anlamlı farklılık olmadığı bulunmuştur $\left(t_{(379)}=-0.435, p>\right.$ $.05)$.

Ortaokul matematik öğretmenlerinin eleştirel düşünme eğilimlerinin kıdeme göre farklılaşma durumlarına ilişkin bulgular Tablo 4'te verilmiştir.

Tablo 4. Kıdeme Göre Ortaokul Matematik Öğretmenlerinin Eleştirel Düşünme Eğilimlerindeki Farklılaşmaya İlişkin Tek Yönlü Varyans Analizi (ANOVA) Sonuçları

\begin{tabular}{|c|c|c|c|c|c|c|c|c|}
\hline Alt Boyutlar & Kıdem & $\mathbf{N}$ & $\overline{\mathbf{X}}$ & Ss & Sd & $\mathbf{F}$ & $p$ & Fark \\
\hline \multirow{4}{*}{ Üstbiliş } & $1.1-5 \mathrm{y} 1 \mathrm{l}$ & 110 & 4.28 & 0.40 & \multirow{4}{*}{3} & \multirow{4}{*}{3.784} & \multirow{4}{*}{$.011^{*}$} & $4-1$ \\
\hline & 2.6-10 y1l & 87 & 4.33 & 0.34 & & & & \\
\hline & $3.11-15$ y1l & 114 & 4.34 & 0.46 & & & & \\
\hline & 4.16 yıl ve üstü & 70 & 4.49 & 0.41 & & & & \\
\hline \multirow{4}{*}{ Esneklik } & $1.1-5 \mathrm{y} 1 \mathrm{l}$ & 110 & 4.26 & 0.45 & \multirow{4}{*}{3} & \multirow{4}{*}{1.854} & \multirow{4}{*}{.137} & \\
\hline & $2.6-10 \mathrm{y} 1 \mathrm{l}$ & 87 & 4.38 & 0.41 & & & & \\
\hline & $3.11-15 \mathrm{y} 1 \mathrm{l}$ & 114 & 4.28 & 0.50 & & & & \\
\hline & 4.16 yıl ve üstü & 70 & 4.39 & 0.56 & & & & \\
\hline \multirow{4}{*}{ Sistematiklik } & $1.1-5 \mathrm{y} 1 \mathrm{l}$ & 110 & 4.30 & 0.42 & \multirow{4}{*}{3} & \multirow{4}{*}{1.002} & \multirow{4}{*}{.392} & \\
\hline & 2.6-10 y1l & 87 & 4.35 & 0.43 & & & & \\
\hline & $3.11-15$ y1l & 114 & 4.25 & 0.49 & & & & \\
\hline & 4.16 yıl ve üstü & 70 & 4.36 & 0.56 & & & & \\
\hline \multirow{4}{*}{ Azim sabır } & $1.1-5 \mathrm{y} 11$ & 110 & 4.27 & 0.47 & \multirow{4}{*}{3} & \multirow{4}{*}{0.696} & \multirow{4}{*}{.555} & \\
\hline & $2.6-10 \mathrm{y} 1 \mathrm{l}$ & 87 & 4.30 & 0.49 & & & & \\
\hline & $3.11-15 \mathrm{y} 1 \mathrm{l}$ & 114 & 4.23 & 0.62 & & & & \\
\hline & 4.16 y1l ve üstü & 70 & 4.34 & 0.61 & & & & \\
\hline \multirow{4}{*}{ Açık fikirlilik } & $1.1-5 \mathrm{y} 1 \mathrm{l}$ & 110 & 4.26 & 0.62 & \multirow{4}{*}{3} & \multirow{4}{*}{2.589} & \multirow{4}{*}{.053} & \\
\hline & $2.6-10 \mathrm{y} 1 \mathrm{l}$ & 87 & 4.15 & 0.56 & & & & \\
\hline & $3.11-15$ y1l & 114 & 4.25 & 0.65 & & & & \\
\hline & 4.16 yıl ve üstü & 70 & 4.41 & 0.47 & & & & \\
\hline \multirow{4}{*}{ Toplam } & $1.1-5 \mathrm{y} 1 \mathrm{l}$ & 110 & 4.28 & 0.38 & \multirow{4}{*}{3} & \multirow{4}{*}{1.631} & \multirow{4}{*}{.182} & \\
\hline & $2.6-10 \mathrm{y} 1 \mathrm{l}$ & 87 & 4.33 & 0.35 & & & & \\
\hline & $3.11-15 \mathrm{y} 1 \mathrm{l}$ & 114 & 4.28 & 0.47 & & & & \\
\hline & 4.16 y1l ve üstü & 70 & 4.41 & 0.48 & & & & \\
\hline
\end{tabular}

Tablo 4'te sunulan bulgular incelendiğinde, kıdeme göre ortaokul matematik öğretmenlerinin sadece üstbiliş puanlarında anlamlı bir farklılığın olduğu görülmektedir $\left(F_{(3,377)}=3.784, p<\right.$ .05). Farkın kaynağını belirlemek için yapılan Tamhane T2 Testi'nin sonucuna göre, 16 yıl ve üstü kıdeme sahip olan öğretmenler üstbiliş alt boyutu puanı $(\overline{\mathrm{X}}=4.49), 1-5$ yıl kıdeme sahip öğretmenlerin puanında $(\overline{\mathrm{X}}=4.28)$ anlamlı düzeyde daha yüksektir.

Ortaokul matematik öğretmenlerinin eleştirel düşünme eğilimlerinin eğitim durumlarına göre farklılaşma durumlarına ilişkin bulgular Tablo 5 'te verilmiştir.

Tablo 5. Hizmet İçi Eğitim Alma Durumuna Göre Ortaokul Matematik Öğretmenlerinin Eleştirel Düşünme Eğilimlerindeki Farklılaşmaya İlişskin Bağımsız Gruplar $t$-testi Sonuçları

\begin{tabular}{|c|c|c|c|c|c|c|c|}
\hline Alt Boyutlar & Hizmet İçi Eğitim & $\mathbf{N}$ & $\overline{\mathbf{X}}$ & Ss & $t$ & Sd & $p$ \\
\hline \multirow{2}{*}{ Üstbiliş } & Evet & 28 & 4.60 & 0.39 & \multirow{2}{*}{3.318} & \multirow{2}{*}{379} & \multirow{2}{*}{$.001 *$} \\
\hline & Hayır & 353 & 4.33 & 0.41 & & & \\
\hline \multirow{2}{*}{ Esneklik } & Evet & 28 & 4.54 & 0.51 & \multirow{2}{*}{2.616} & \multirow{2}{*}{379} & \multirow{2}{*}{$.009 *$} \\
\hline & Hayır & 353 & 4.30 & 0.47 & & & \\
\hline \multirow{2}{*}{ Sistematiklik } & Evet & 28 & 4.57 & 0.45 & \multirow{2}{*}{3.055} & \multirow{2}{*}{379} & \multirow{2}{*}{$.002 *$} \\
\hline & Hayır & 353 & 4.29 & 0.47 & & & \\
\hline
\end{tabular}


Tablo 5. (devam1)

\begin{tabular}{|c|c|c|c|c|c|c|c|}
\hline Alt Boyutlar & Hizmet İçi Eğitim & $\mathbf{N}$ & $\overline{\mathbf{X}}$ & Ss & $t$ & Sd & $p$ \\
\hline \multirow{2}{*}{ Azim Sabır } & Evet & 28 & 4.57 & 0.51 & \multirow{2}{*}{2.923} & \multirow{2}{*}{379} & \multirow{2}{*}{$.004 *$} \\
\hline & Hayır & 353 & 4.26 & 0.55 & & & \\
\hline \multirow{2}{*}{ Açık Fikirlilik } & Evet & 28 & 4.65 & 0.37 & \multirow{2}{*}{5.366} & \multirow{2}{*}{38.81} & \multirow{2}{*}{$.000^{*}$} \\
\hline & Hayır & 353 & 4.23 & 0.60 & & & \\
\hline \multirow{2}{*}{ Toplam } & Evet & 28 & 4.58 & 0.43 & \multirow{2}{*}{3.451} & \multirow{2}{*}{379} & \multirow{2}{*}{$.001 *$} \\
\hline & Hayır & 353 & 4.29 & 0.41 & & & \\
\hline
\end{tabular}

Tablo 5 incelendiğinde öğretmenlerin eleştirel düşünme eğilim algıları puan ortalamalarında eğitim alan öğretmenler lehinde anlamlı farkl1lık olduğu $\left(t_{(379)}=3.451, p<.05\right)$ görülmektedir. Ayrıca tüm alt boyutlarda da eğitim alan öğretmenler lehinde anlamlı farklılık görülmektedir. $\mathrm{Bu}$ bulguya göre, hizmet içi eğitim almanın öğretmenlerin eleştirel düşünme eğilim algılarını artırabileceği söylenebilir.

Araştırmanın üçüncü alt problemi kapsamında ortaokul matematik öğretmenlerinin eleştirel düşünme öğretimi uygulama algıları düzeyi incelenmiştir. Elde edilen bulgular Tablo 6'da sunulmuştur.

Tablo 6. Eleştirel Düşünme Öğretimi Uygulama Ölçeğinin Alt Boyutlarına Ait Betimsel İstatistikleri

\begin{tabular}{lccccc}
\hline \multicolumn{1}{c}{ Alt Boyutlar } & $\mathbf{N}$ & Min & Max & $\overline{\mathbf{X}}$ & Ss \\
\hline Öğretim Ortamı & 381 & 2.86 & 5.00 & 4.33 & 0.50 \\
Öğretmen Nitelikleri & 381 & 3.00 & 5.00 & 4.61 & 0.44 \\
Sinıf Atmosferi & 381 & 3.33 & 5.00 & 4.72 & 0.37 \\
Kendini İfade Etme & 381 & 2.00 & 5.00 & 4.43 & 0.56 \\
Toplam & 381 & 3.33 & 5.00 & 4.48 & 0.38 \\
\hline
\end{tabular}

Tablo 6'da sunulan bulgulara göre, ortaokul matematik öğretmenlerinin eleştirel düşünme öğretim uygulama düzeyi ölçeğinin gerek ölçek toplam puan ortalamasında, gerekse tüm boyut ortalamalarında çok yüksek olduğu görülmektedir.

Araştırmanın dördüncü alt problemi kapsamında ortaokul matematik öğretmenlerinin eleştirel düşünme öğretimi uygulama algılarındaki farklılaşma durumu cinsiyet, kıdem ve eleştirel düşünme ile ilgili eğitim alma durumlarına göre incelenmiştir. Cinsiyete göre farklılaşma durumuna ilişkin bulgular Tablo 7'te sunulmuştur.

Tablo 7. Cinsiyete Göre Ortaokul Matematik Öğretmenlerinin Eleştirel Düşünme Öğretimi Uygulamalarındaki Farklılaşmaya İlişkin Bağımsız Gruplar $t$-testi Sonuçları

\begin{tabular}{|c|c|c|c|c|c|c|c|}
\hline Alt Boyutlar & Cinsiyet & $\mathbf{N}$ & $\overline{\mathbf{X}}$ & Ss & $t$ & Sd & $p$ \\
\hline \multirow{2}{*}{ Öğretim Ortamı } & Kadın & 246 & 4.29 & 0.49 & \multirow{2}{*}{-2.159} & \multirow{2}{*}{379} & \multirow{2}{*}{$.031^{*}$} \\
\hline & Erkek & 135 & 4.40 & 0.51 & & & \\
\hline \multirow{2}{*}{ Öğretmen Nitelikleri } & Kadın & 246 & 4.61 & 0.42 & \multirow{2}{*}{0.215} & \multirow{2}{*}{379} & \multirow{2}{*}{.830} \\
\hline & Erkek & 135 & 4.60 & 0.48 & & & \\
\hline \multirow{2}{*}{ Sinif Atmosferi } & Kadın & 246 & 4.70 & 0.38 & \multirow{2}{*}{-1.528} & \multirow{2}{*}{303.94} & \multirow{2}{*}{.127} \\
\hline & Erkek & 135 & 4.76 & 0.34 & & & \\
\hline \multirow{2}{*}{ Kendini İfade Etme } & Kadın & 246 & 4.41 & 0.53 & \multirow{2}{*}{-1.306} & \multirow{2}{*}{379} & \multirow{2}{*}{.192} \\
\hline & Erkek & 135 & 4.48 & 0.59 & & & \\
\hline \multirow{2}{*}{ Toplam } & Kadın & 246 & 4.45 & 0.37 & \multirow{2}{*}{-1.818} & \multirow{2}{*}{379} & \multirow{2}{*}{.070} \\
\hline & Erkek & 135 & 4.52 & 0.39 & & & \\
\hline
\end{tabular}


Tablo 7'de sunulan bulgular incelendiğinde, ortaokul matematik öğretmenlerinin eleștirel düşünme öğretimi uygulama algılarının öğretim ortamı alt boyutunda cinsiyete göre anlamlı bir farklılık olduğu bulunmuştur $\left(t_{(379)}=-2.159, p<.05\right)$. Gruplar arasındaki bu fark, erkek öğretmenlerin öğretim ortamı puanlarının $(\bar{X}=4.40)$ kadın öğretmenlerin puanlarından $(\bar{X}=4.29)$ anlamlı derecede yüksek olmasından kaynaklanmaktadır. Eleştirel düşünme öğretimi uygulama düzeyi ölçeğinin diğer boyutlarında cinsiyete göre anlamlı bir farklılık bulunmamıştır

Ortaokul matematik öğretmenlerinin eleştirel düşünme öğretim uygulama algılarının kıdeme göre farklılaşma durumlarına ilişkin bulgular Tablo 8'de sunulmuştur.

Tablo 8. Kıdeme Göre Ortaokul Matematik Öğretmenlerinin Eleştirel Düşünme Öğretimi Uygulamalarındaki Farklılaşmaya İlişkin Tek Yönlü Varyans Analizi (ANOVA) Sonuçları

\begin{tabular}{|c|c|c|c|c|c|c|c|c|}
\hline Alt Boyutlar & Kıdem & $\mathbf{N}$ & $\overline{\mathbf{X}}$ & Ss & Sd & $\mathbf{F}$ & $p$ & Fark \\
\hline \multirow{4}{*}{ Öğretim Ortamı } & $1.1-5 \mathrm{y} 1 \mathrm{l}$ & 110 & 4.39 & 0.48 & \multirow{4}{*}{3} & \multirow{4}{*}{2.551} & \multirow{4}{*}{.055} & \\
\hline & $2.6-10 \mathrm{y} 1 \mathrm{l}$ & 87 & 4.27 & 0.57 & & & & \\
\hline & $3.11-15 \mathrm{y} 1 \mathrm{l}$ & 114 & 4.26 & 0.50 & & & & \\
\hline & 4.16 y1l ve üstü & 70 & 4.42 & 0.44 & & & & \\
\hline \multirow{4}{*}{ Öğretmen Nitelikleri } & $1.1-5 \mathrm{y} 1 \mathrm{l}$ & 110 & 4.67 & 0.43 & \multirow{4}{*}{3} & \multirow{4}{*}{4.016} & \multirow{4}{*}{$.008 *$} & $4-3$ \\
\hline & $2.6-10$ y1l & 87 & 4.54 & 0.43 & & & & \\
\hline & $3.11-15 \mathrm{y} 1 \mathrm{l}$ & 114 & 4.53 & 0.45 & & & & \\
\hline & 4.16 y1l ve üstü & 70 & 4.71 & 0.41 & & & & \\
\hline \multirow{4}{*}{ Sinif Atmosferi } & $1.1-5 \mathrm{y} 1 \mathrm{l}$ & 110 & 4.76 & 0.35 & \multirow{4}{*}{3} & \multirow{4}{*}{1.428} & \multirow{4}{*}{.234} & \\
\hline & $2.6-10$ y1l & 87 & 4.70 & 0.40 & & & & \\
\hline & $3.11-15 \mathrm{y} 1 \mathrm{l}$ & 114 & 4.68 & 0.37 & & & & \\
\hline & 4.16 y1l ve üstü & 70 & 4.78 & 0.37 & & & & \\
\hline \multirow{4}{*}{ Kendini İfade Etme } & $1.1-5 \mathrm{y} 11$ & 110 & 4.49 & 0.58 & \multirow{4}{*}{3} & \multirow{4}{*}{1.146} & \multirow{4}{*}{.330} & \\
\hline & $2.6-10$ y1l & 87 & 4.45 & 0.50 & & & & \\
\hline & $3.11-15$ y1l & 114 & 4.35 & 0.58 & & & & \\
\hline & 4.16 y1l ve üstü & 70 & 4.46 & 0.54 & & & & \\
\hline \multirow{4}{*}{ Toplam } & $1.1-5 \mathrm{y} 1 \mathrm{l}$ & 110 & 4.53 & 0.35 & \multirow{4}{*}{3} & \multirow{4}{*}{3.391} & \multirow{4}{*}{$.018 *$} & $4-3$ \\
\hline & $2.6-10$ yil & 87 & 4.43 & 0.42 & & & & \\
\hline & $3.11-15$ y1l & 114 & 4.41 & 0.39 & & & & \\
\hline & 4.16 yil ve üstü & 70 & 4.56 & 0.34 & & & & \\
\hline
\end{tabular}

Tablo 8'de göre öğretmenlerin eleştirel düşünme öğretim uygulamaları toplam puanlarında kıdemlerine göre anlamlı bir farklılığın olduğu görülmektedir $\left(F_{(3,377)}=3.391, p<.05\right)$. Farkın kaynağını belirlemek için yapılan Scheffe testinin sonuçlarına göre, 16 yıl ve üstü kıdeme sahip olan öğretmenlerin puanları ( $\overline{\mathrm{X}}=4.56), 11-15$ yıl kıdeme sahip öğretmenlerin puanlarından $(\overline{\mathrm{X}}=$ 4.41) anlamlı düzeyde daha yüksektir. Tablo 9'da gruplar arasında anlamlı farkın bulunduğu bir diğer boyut ise öğretmen nitelikleridir $\left(F_{(3,377)}=4.016, p<.05\right)$. Farkın kaynağını belirlemek için yapılan Tamhane T2 testinin sonuçlarına göre, 16 y1l ve üstü kıdeme sahip olan öğretmenlerin puanları $(\overline{\mathrm{X}}=4.71), 11-15$ yıl kıdeme sahip öğretmenlerin puanlarından $(\overline{\mathrm{X}}=4.53)$ anlamlı düzeyde daha yüksektir.

Hizmet içi eğitim alma durumlarına göre, öğretmenlerin eleştirel düşünme öğretim uygulamalarındaki farklılaşma durumlarını incelemek için analiz sonuçları Tablo 9'da sunulmuştur. 
Tablo 9. Hizmet İçi Eğitim Alma Durumuna Göre Ortaokul Matematik Öğretmenlerinin Eleştirel Düşünme Öğretimi Uygulamalarındaki Farklılaşmaya İlişkin Bağımsız Gruplar $t$-testi Sonuçları

\begin{tabular}{|c|c|c|c|c|c|c|c|}
\hline Alt Boyutlar & $\begin{array}{c}\text { Hizmet İçi } \\
\text { Eğitim }\end{array}$ & $\mathbf{N}$ & $\overline{\mathbf{X}}$ & Ss & $t$ & Sd & $p$ \\
\hline \multirow{2}{*}{ Öğretim Ortamı } & Evet & 28 & 4.67 & 0.41 & \multirow{2}{*}{3.771} & \multirow{2}{*}{379} & \multirow{2}{*}{$.000 *$} \\
\hline & Hayır & 353 & 4.30 & 0.50 & & & \\
\hline \multirow{2}{*}{ Öğretmen Nitelikleri } & Evet & 28 & 4.95 & 0.11 & \multirow{2}{*}{11.216} & \multirow{2}{*}{111.99} & \multirow{2}{*}{$.000 *$} \\
\hline & Hayır & 353 & 4.85 & 0.44 & & & \\
\hline \multirow{2}{*}{ Sinıf Atmosferi } & Evet & 28 & 4.90 & 0.21 & \multirow{2}{*}{4.092} & \multirow{2}{*}{41.27} & \multirow{2}{*}{$.000 *$} \\
\hline & Hayır & 353 & 4.71 & 0.38 & & & \\
\hline \multirow{2}{*}{ Kendini İfade Etme } & Evet & 28 & 4.66 & 0.47 & \multirow{2}{*}{2.193} & \multirow{2}{*}{379} & \multirow{2}{*}{$.029 *$} \\
\hline & Hayır & 353 & 4.42 & 0.56 & & & \\
\hline \multirow{2}{*}{ Toplam } & Evet & 28 & 4.77 & 0.27 & \multirow{2}{*}{5.663} & \multirow{2}{*}{35.91} & \multirow{2}{*}{$.000^{*}$} \\
\hline & Hayır & 353 & 4.45 & 0.38 & & & \\
\hline
\end{tabular}

Tablo 9 incelendiğinde öğretmenlerin eleştirel düşünme öğretimi uygulama algıları toplam puanlarında $\left(t_{(35.91)}=5.663, p<.05\right)$ ve öğretim ortamı $\left(t_{(379)}=3.77, p<.05\right)$, öğretmen nitelikleri $\left(t_{(111.99)}=3.77, p<.05\right)$, sinif atmosferi $\left(t_{(41.27)}=3.77, p<.05\right)$ ve kendini ifade etme $\left(t_{(379)}=2.19, p<.05\right)$ alt boyutlarının tamamında gruplar arasında anlamlı farklılık olduğu, farkın hizmet içi eğitim alan grubun eleştirel düşünme öğretimi uygulama algılarının bu eğitimi almayan gruba göre anlamlı düzeyde daha yüksek olmasından kaynaklandığı bulunmuştur.

Araştırmanın beşinci alt problemi kapsamında ortaokul matematik öğretmenlerinin eleştirel düşünme eğilimleri ile eleştirel düşünme öğretimi uygulama düzeyleri arasında anlamlı bir ilişki incelenmiştir. Elde edilen bulgular Tablo 10’da sunulmuştur.

Tablo 10. Ortaokul Matematik Öğretmenlerinin Eleştirel Düşünme Eğilimleri ve Uygulama Algıları Arasındaki İlişkilere Yönelik Pearson Korelasyon Analizi Sonuçları

\begin{tabular}{lcccccccc}
\hline & 1 & 2 & 3 & 4 & 5 & 6 & 7 & 8 \\
\hline 1. Üstbiliş & & & & & & & & \\
2. Esneklik & $.81^{* *}$ & & & & & & & \\
3. Sistematiklik & $.69^{* *}$ & $.79 * *$ & & & & & & \\
4. Azim-Sabır & $.67^{* *}$ & $.71^{* *}$ & $.79^{* *}$ & & & & & \\
5. Aç1k fikirlilik & $.51^{* *}$ & $.56^{* *}$ & $.62^{* *}$ & $.62^{* *}$ & & & & \\
6. Öğretim ortamı & $.43^{* *}$ & $.43^{* *}$ & $.47^{* *}$ & $.55^{* *}$ & $.48^{* *}$ & & & \\
7. Öğretmen nitelik & $.33^{* *}$ & $.30^{* *}$ & $.29^{* *}$ & $.31^{* *}$ & $.48^{* *}$ & $.47^{* *}$ & & \\
8. Sinıf atmosferi & $.30^{* *}$ & $.24^{* *}$ & $.27^{* *}$ & $.30^{* *}$ & $.34^{* *}$ & $.51^{* *}$ & $.3 * *$ & \\
9. Kendini ifade & $.44^{* *}$ & $.43^{* *}$ & $.41^{* *}$ & $.47^{* *}$ & $.42^{* *}$ & $.55^{* *}$ & $.39^{* *}$ & $.42^{* *}$ \\
\hline$* *<01$
\end{tabular}

$* * \mathrm{p}<.01$

Tablo 10'da sunulan bulgular incelendiğinde eleştirel düşünme eğilim alt boyutları ile eleştirel düşünme öğretim uygulama algıları alt boyutları arasındaki ilişkilerin pozitif yönde ve .01 düzeyinde anlamlı olduğu görülmektedir. Değişkenler arasındaki ilişkilerin gücüne bakıldığında ise, en yüksek ilişkinin .55 ile azim ve sabır ile öğretim ortamı alt boyutları arasında, en düşük ilişkinin ise .24 ile esneklik ve sınıf atmosferi alt boyutları arasında olduğu bulunmuştur.

Araştırmanın altıncı alt problemi kapsamında ortaokul matematik öğretmenlerinin eleştirel düşünme eğilim alg1 düzeylerinin eleştirel düşünme öğretimi uygulama alg1 düzeylerini yordama gücü incelenmiştir. $\mathrm{Bu}$ amaçla yapılan çoklu doğrusal regresyon analizi için varsayımlar edilmiştir. Bu kapsamda, normallik, doğrusallık, çoklu ortak doğrusallık ve eş varyanslılık varsayımları incelenmiş ve tüm değerlerin referans aralıklarında olduğu (VIF değerleri 1.78 ile 4.24 arasında, tolerance değerleri .23 ile .56 arasında değişmektedir), herhangi 
bir varsayımın ihlal edilmediği görülmüştür. Analiz sonucunda elde edilen bulgular Tablo 11'de verilmiştir.

Tablo 11. Ortaokul Matematik Öğretmenlerinin Eleştirel Düşünme Eğilimlerinin Eleştirel Düşünme Öğretimi Uygulama Algılarını Yordama Gücüne Yönelik Çoklu Doğrusal Regresyon Analizi Sonuçları

\begin{tabular}{lccccccc}
\hline \multicolumn{1}{c}{ Değişken } & B & $\begin{array}{c}\text { Standart } \\
\text { Hata }\end{array}$ & $\boldsymbol{\beta}$ & $\boldsymbol{t}$ & $\boldsymbol{p}$ & $\begin{array}{c}\text { Ikili } \\
\mathbf{r}\end{array}$ & $\begin{array}{c}\text { Kismi } \\
\mathbf{r}\end{array}$ \\
\hline Sabit & 2.26 & .16 & - & 13.60 & .00 & - & - \\
Üstbiliş & .16 & .06 & .18 & 2.60 & .01 & .491 & .133 \\
Esneklik & -.03 & .06 & -.04 & -0.51 & .60 & .470 & -.027 \\
Sistematiklik & -.04 & .06 & -.05 & -0.67 & .50 & .492 & -.035 \\
Azim ve Sabır & .21 & .04 & .31 & 4.39 & .00 & .566 & .221 \\
Açık Fikirlilik & .21 & .03 & .32 & 6.16 & .00 & .560 & .303 \\
\hline $\mathrm{R}=.635$ & & $\mathrm{R}^{2}=.403$ & & & & & \\
$\mathrm{~F}_{(5,375)}=50.694$ & & $p=.000$ & & & & & \\
\hline
\end{tabular}

Tablo 11 'te sunulan bulgular incelendiğinde, eleştirel düşünme eğiliminin alt boyutları olan üstbiliş, esneklik, sistematiklik, azim ve sabır ile açık fikirlilik değişkenlerini, eleştirel düşünme öğretimi uygulama algılarını anlamlı düzeyde yordadığı görülmektedir $\left(\mathrm{F}_{(5,375)}=50.694 ; p<\right.$ .01). Eleştirel düşünme eğilimini oluşturan alt boyutlar, eleştirel düşünme öğretimi uygulama algılarındaki varyansın yaklaşık \%40'ını açıklamaktadır $\left(\mathrm{R}=.635, \mathrm{R}^{2}=.403\right)$.

Modelde yer alan bağımsız değişkenlerin göreli önem sırasını incelemek için standardize edilmiş regresyon katsayılarına bakılmıştır. Ortaokul matematik öğretmenlerinin eleștirel düşünme öğretimi uygulama algılarını en fazla yordayan değişkenin açık fikirlilik $(\beta=.32)$ olduğu, bunu sırayla azim ve sabır $(\beta=.31)$ ile üstbilişin $(\beta=.18)$ takip ettiği, sistematiklik $(\beta=-.05)$ ve esneklik $(\beta=-.04)$ boyutlarının modele katkılarının ise istatistiksel olarak anlamlı olmadığı bulunmuştur.

\section{Tartışma ve Sonuçlar}

$\mathrm{Bu}$ araştırmada ortaokul matematik öğretmenlerinin eleştirel düşünme eğilim ve uygulama alg1 düzeyleri arasındaki ilişki incelenmiştir. Bu kapsamda öncelikle düşünme eğilim ve uygulama algılarında cinsiyet, kıdem ve eleştirel düşünme ile ilgili eğitim alma değişkenlere göre gruplar arasındaki farklılıklar incelenmiş ve daha sonra değişkenler arası ilişkiler analiz edilmiştir. Elde edilen sonuçlarda ortaokul matematik öğretmenlerinin eleştirel düşünme eğilimleri uygulama alg1 düzeylerinin çok yüksek düzeyde olduğu tespit edilmiştir. Öğretmenlerin eleştirel düşünmenin bir alt boyutu olan üstbiliş eğilimlerinin yüksek olması, onların görevlerini başarılı bir şekilde planlayabildikleri, öğrencilerin öğrenme süreçlerini iyi bir şekilde izleyebildikleri ve öğrenme stratejilerini etkili bir şekilde kullanabildiklerini göstermektedir. Esneklik alt boyut eğilimlerinin yüksek olması, öğretmenlerin aksine deliller sunulduğunda iddialarından vazgeçebileceklerini, sistematiklik eğilimlerinin yüksek olması, öğretmenlerin planlı ve örgütlü bir şekilde iş yapabildikleri ve belli bir yönteme göre karar verebildiklerini, azim ve sabır alt boyut eğilimlerinin yüksek olması, öğretmenlerin zorluklar karşısında vazgeçmeden işi çözüme götürme çabası içinde olabileceklerini, açık fikirlilik alt boyut eğilimlerinin yüksek olması ise öğretmenlerin farklı fikirlere açık olduklarını göstermektedir. Elde edilen bu sonuç Kandemir (2017) ve Küçük'ün (2007) öğretmen adayları ile yaptıkları çalışma sonuçları ile örtüşürken Kürüm (2002) ve Beşoluk ve Önder'in (2010) öğretmen adayları ile yaptıkları çalışma sonuçları ile farklılık göstermektedir. Kandemir (2017) ve Küçük (2007) öğretmen adaylarının eleştirel düşünme eğilim düzeylerinin yüksek olduğu sonucuna ulaşırken, Kürüm (2002) öğretmen adaylarının eleştirel düşünme eğilim düzeylerinin düşük olduğu, Beşoluk ve Önder (2010) ise orta düzeyde eleştirel düşünme eğilimine sahip olduklarını bulmuştur. 
Araştırmada öğretmenlerin eleştirel düşünme eğilimlerinin cinsiyete göre anlamlı farklılık göstermediği, kadın ve erkek matematik öğretmenlerin eleştirel düşünme eğilim algılarının benzer olduğu bulunmuştur. Elde edilen bu sonuç, Kürüm (2002) ve Demirtaş'in (2019) sonuçları ile örtüşürken Hayran'ın (2000) sonuçları ile farklılık göstermektedir. Hayran (2000) araştırmasında kadın öğretmenler lehine fark bulmuştur.

Araştırmada k1deme göre öğretmenlerin eleştirel düşünme eğilimlerinin sadece üstbiliş alt boyutunda anlamlı bir fark olduğu, diğer boyutlarda gruplar arasındaki farkın istatistiksel olarak anlamlı olmadığı bulunmuştur. Üstbiliş alt boyutunda 16 yıl ve üstü kıdeme sahip olan öğretmenlerin puanlarının 1-5 yıl kıdeme sahip öğretmenlere göre daha yüksek olduğu bulunmuştur. Araştırmada elde edilen bu sonuç Hayran (2000) ve Beşoluk ve Önder'in (2010) sonuçları ile benzerlik göstermektedir.

Hizmet içi eğitim alma durumuna göre ortaokul matematik öğretmenlerinin, eleştirel düşünme eğilimlerinde anlamlı düzeyde farklılık olduğu, eğitim alanların puanlarının almayanlara göre anlamlı düzeyde yüksek olduğu bulunmuştur. Schreglmann (2011), öğretmen adayları üzerinde yürüttüğü çalışmasında eleştirel düşünme öğretimine ilişkin eğitim almanın öğretmen adaylarının eleştirel düşünme eğilimlerini anlamlı düzeyde artırdığı sonucuna ulaşmıştır. Benzer şekilde öğretmen adaylarının eleştirel düşünme eğitimi almalarının eleştirel düşünme seviyelerini artırdığına yönelik araştırmalar bulunmaktadır (Akdere, 2012; Güner, 2015; Gündüz, 2017; Tok \& Sevinç, 2010).

Araştırmada öğretmenlerin eleştirel düşünme öğretimi uygulama algılarının çok yüksek düzeyde olduğu tespit edilmiştir. Buna göre öğretmenlerin, kendilerini öğrencilerin eleştirel düşünme becerilerini geliştirici öğretim uygulamalarına derslerinde her zaman yer verdikleri şeklinde algıladıkları söylenebilir. Öğretmenlerin öğretim ortamı alt boyutu uygulama algı düzeylerinin yüksek olması, öğrencilerin çok yönlü düşünmelerini sağlayacakları ortamlar oluşturduklarını, onlara tartışma ortamı sağlayacak etkinlikler düzenlediklerini, öğrencilerinden konuyu çeşitli kaynaklardan araştırmalarını istedikleri anlamına gelmektedir. Öğretmen nitelikleri alt boyutu uygulama alg1 düzeylerinin yüksek olması, öğretmenlerin öğrencilerine hoşgörülü davrandıkları, onları soru sormaları için cesaretlendirdikleri ve düşüncelerine değer verdiklerini göstermektedir. Öğretmenlerin sınıf atmosferi alt boyutu uygulama alg1 düzeylerinin yüksek olması, onların öğrencilerini derse aktif katılımları için cesaretlendirdikleri, birbirlerinin düşüncelerine karşı saygı duymalarını sağladıkları ve soruları cevaplamaları için yeterince süre verdiklerini göstermektedir. Öğretmenlerin kendini ifade etme alt boyutu uygulama alg1 düzeylerinin yüksek olması, öğrencilerinin düşüncelerini savunabilecekleri ortamlar oluşturdukları ve kendilerini değerlendirme olanağı sağladıklarını göstermektedir. Elde edilen bu sonuçlar, Aslan (2019) tarafindan yapılan ve sosyal bilgiler öğretmenlerinin eleştirel düşünme öğretimine ilişkin yönelimlerinin olumlu düzeyde olduğu, öğretmenlerin ezberci eğitimden ziyade yaşantı merkezli eğitimden yana olduklarına yönelik bulgusuyla benzerlik göstermektedir. Karadeniz (2006) tarafından yapılan araştırmada ise öğretmenlerin eleştirel düşünme öğretimine olumlu yaklaştıkları bulunmuştur. Akdere (2012) tarafından yapılan çalışmanın sonucunda ise öğretmen adaylarının eleştirel düşünme öğretimine yönelik tutumlarının orta düzeyde olduğu bulunmuş̧tur.

Araştırmada eleştirel düşünme öğretimi uygulama alg1 düzeylerinin cinsiyete göre farklılaşmadığı, kadın ve erkek ortaokul matematik öğretmenlerinin eleştirel düşünme öğretimi uygulama düzeylerinin benzer olduğu bulunmuştur. Elde edilen bu sonuç, Gelen (1999) ve Akdere'nin (2012) sonuçlarıyla benzerlik göstermektedir. Karadeniz (2006) ve Söğüt (2009) ise çalışmalarında kadın öğretmenlerin eleştirel düşünme öğretimi uygulama algı düzeylerinin erkek öğretmenlere göre daha yüksek olduğunu bulmuştur. 
Araştırmada eleştirel düşünme öğretimi uygulamalarında ölçek toplam puanında ve öğretmen nitelikleri alt boyutunda kıdeme göre anlamlı bir fark olduğu, 16 yıl ve üstü kıdeme sahip öğretmenlerin, k1demi 11-15 y1l olan öğretmenlerden daha yüksek puanlara sahip olduğu bulunmuştur. Buna göre ortaokul matematik öğretmenlerinin mesleki deneyimleri arttıkça eleștirel düşünme öğretimi uygulamalarına daha fazla yer verecekleri söylenebilir. Elde edilen bu sonuç, Göbel (2013) sınıf öğretmenleri ile yapılan ve mesleki deneyimi yüksek olan öğretmenler lehine sonuç bulunan çalışma ile örtüşürken Gelen (1999) tarafindan yapılan ve sınıf öğretmenlerinin kıdemlerine göre eleştirel düşünme becerileri öğretim uygulamalarının farklılaşmadığı yönelik sonuçlarıyla farklılık göstermektedir. Sögüt (2009) tarafından yapılan çalışmada ise kıdemi az olan matematik ögretmenlerinin eleştirel düşünmeyi kazandırmaya yönelik çalışmalara daha fazla yer verdikleri bulunmuştur.

Araştırmaya katılan öğretmenlerin eleştirel düşünme öğretimi uygulama düzeylerinde eleştirel düşünme ile ilgili hizmet içi eğitim alma değişkenine göre eğitim alanlar lehinde anlamlı farklılık görülmüştür. Bu sonuca göre eleştirel düşünme ile ilgili eğitim almanın matematik öğretmenlerinin eleştirel düşünme becerisini geliştirici öğretim uygulamalarının düzeyini artırdığı, eğitim alan öğretmenlerin eleştirel düşünmeyi geliștirici uygulamalara daha fazla yer verdikleri söylenebilir. Akınoğlu (2001) yaptığı çalışmada eleştirel düşünme becerilerini temel alan fen öğretiminin öğretmen adaylarının eleştirel düşünme becerileri uygulama düzeylerini artırdığını ifade etmiştir. Akdere (2012) yapmış olduğu çalışmada eleştirel düşünme ile ilgili eğitim alan öğretmen adaylarının eleştirel düşünme öğretimine yönelik tutumlarının anlamlı derecede arttı̆̆ını bulmuştur.

Araştırmada öğretmenlerin eleştirel düşünme eğilim düzeyleri ile eleştirel düşünme öğretimi uygulama algıları arasında orta düzey, pozitif yönde anlamlı ilişki bulunmuştur. Bu sonuca göre ortaokul matematik öğretmenlerinin eleştirel düşünme eğilim düzeyleri arttıkça eleştirel düşünme becerisini geliştirici öğretim uygulamalarını kullanma düzeyleri de artmaktadır. Ayrıca eleştirel düşünme eğilim düzeyinin eleştirel düşünme öğretimi uygulama alg1 düzeyindeki varyansın yaklaşık \%40'1nı açıkladığ 1 , ortaokul matematik öğretmenlerinin eleştirel düşünme öğretimi uygulama algılarını en fazla yordayan değişkenlerin ise sırayla açık fikirlilik, azim ve sabır ve üstbiliş olduğu bulunmuştur. Elde edilen bu sonuç ile ilgili literatür incelendiğinde, Şahin (2014) tarafından yapılan araştırmada, İngilizce öğretmenlerinin eleştirel düşünme eğilim düzeyleri ile eleştirel düşünme stratejilerini kullanma düzeyleri arasında orta düzeyde pozitif ve anlamlı bir ilişki olduğu bulunmuştur. Bir başka çalışmada, Türkçe ve Türk Dili ve Edebiyatı öğretmenlerinin eleştirel düşünme beceri düzeyleri ile eleştirel düşünmeyi artırıcı uygulama düzeyleri arasında yüksek düzeyde pozitif ve anlamlı bir ilişki olduğunu bulunmuştur (Yıldırım, 2005). Bu sonuçlar araştırmadan elde edilen sonuçları desteklemektedir. Akdere (2012) ise öğretmen adaylarının eleştirel düşünme beceri seviyeleri ile eleştirel düşünme öğretimine yönelik tutum seviyeleri arasında anlamlı bir ilişki olmadığı sonucuna ulaşmıştır.

Araştırmadan elde edilen sonuçlar genel olarak değerlendirildiğinde araştırmacılara ve uygulamacılara yönelik çeşitli önerilerde bulunulabilir. Öncelikle bu araştırmada toplanan veriler öz-bildirime dayalı tekniklerle elde edilmiştir dolayısıyla gözlem ve görüşme gibi tekniklerden toplanan verilerle birlikte değerlendirilmesi konunun çok boyutlu ve daha kapsamlı anlaşılmasına katkı sağlayabilir. Ayrıca bu çalışma Düzce, Karabük, Kastamonu ve Çorum olmak üzere dört ildeki matematik öğretmenleri ile gerçekleştirilmiştir. Araştırmanın farklı örneklemlerle tekrar edilmesi sonuçların genellenebilirliğine daha fazla katkı sağlayabilir.

Eleştirel düşünmenin 21. Yüzyıl becerilerinden biri olduğu ve uygulamada sağlayacağı katkılar göz önüne alınırsa, matematik öğretmenlerinin eleştirel düşünme becerisini geliştirmeye yönelik uyguladıkları yöntem, teknik ve etkinliklerin neler olduğu belirlenerek bu konuda öğretmenlere rehberlik edilmesi bu becerilerin öğrencilere kazandırılmasında önemli bir rol oynayabilir. 
Öğretmen adayları için eğitim fakültelerinde öğretim elemanları tarafından, aktif görev yapan öğretmenler için ise milli eğitim müdürlükleri ve idareciler tarafından eleştirel düşünme eğilimlerinin geliştirilmesi ve desteklenmesine uygun ortamlar oluşturulabilir, eleştirel düşünme konusunda kendilerini yeterli görmeyen öğretmenlere hizmet içi eğitimler yoluyla bu becerilerin kazandırılması sağlanabilir.

Matematik ders kitaplarında, öğretmenlere de yardımcı olacak şekilde, eleştirel düşünme becerisini geliştirici uygulama ve etkinliklere daha fazla yer verilmesi bu becerilerin uygulamaya aktarılmasına yardımcı olabilir.

\section{Kaynaklar}

Adams, M. H., Whitlow, J. F., Stover, L. M., \& Johnson, K. W. (1999). A longitudinal evaluation of beccalaureate students' critical thinking abilities. Journal of Nursing Education, 38(3), 139-141.

Akbulut, H. (2019). Fen bilimleri ögrretmen adaylarının eleştirel düşünme eğilimlerinin tespiti ve çeşitti değişkenler açısından incelenmesi (Yayımlanmamış yüksek lisans tezi). Trabzon Üniversitesi Lisansüstü Eğitim Enstitüsü, Trabzon.

Akdere, N. (2012). Turkishpre-service teachers' critical thinking levels, attitudes and selfefficacy beliefs in teaching for critical thinking (Yayımlanmamış doktora tezi). Ortadoğu Teknik Üniversitesi Sosyal Bilimler Enstitüsü, Ankara.

Akınoğlu, O. (2001). Eleştirel düşünme becerilerini temel alan fen bilgisi ögretiminin ögrenme ürünlerine etkisi (Yayımlanmamış doktora tezi). Hacettepe Üniversitesi Sosyal Bilimler Enstitüsü, Ankara.

Annable, C. J. (2006). Developing critical thinking skills and mathematical problem solving ability in grade six students (Unpublished master dissertation). The University of Nipissing.

Aoki, S. (2018). The effects of critical thinking in internationel baccalaureate classes in Japan (Unpublished doctoral dissertation). Union University.

Aslan, S. (2010). Ortä̈ğretim 10. sinıf ögrrencilerinin üst bilimsel süreç ve eleştirel düşünme becerilerinin gelişstirilmesine bilimsel tartışma odakl öğretim yaklaşımının etkisi (Yayımlanmamış doktora tezi). Gazi Üniversitesi Eğitim Bilimleri Enstitüsü, Ankara.

Aslan, D. C. (2019). Sosyal bilgiler ögretmenlerinin eleştirel düşünme düzeylerine yönelik algılarının belirlenmesi (Yayımlanmamış yüksek lisans tezi). Erciyes Üniversitesi, Eğitim Bilimleri Enstitüsü, Kayseri.

Aşık, S. (2018). Biyoloji öğretmenlerinin eleştirel düşünme düzeyleri: Trabzon örneği (Yayımlanmamış yüksek lisans tezi). Karadeniz Teknik Üniversitesi, Eğitim Bilimleri Enstitüsü, Trabzon.

Bayram, D. (2015). The effects of webquest-supported critical thinking instruction on the critical thinking disposition level and 12 writing performance of Turkish pre-service efl teachers (Yayımlanmamış yüksek lisans tezi). Marmara Üniversitesi Eğitim Bilimleri Enstitüsü, İstanbul.

Beşoluk, Ş., \& Önder, İ. (2010). Öğretmen adaylarının öğrenme yaklaşımları, öğrenme stilleri ve eleştirel düşünme eğilimlerinin incelenmesi. İlköğretim Online, 9(2), 679-693.

Bilen, M. (2006). Plandan uygulamaya öğretim (7. basım). Ankara: Anı Yayıncılık.

Büyükkaragöz, S., \& Çivi, C. (1999). Genel öğretim metodları (10. basım). İstanbul: Beta Yayıncilik. 
Büyüköztürk, Ş., Kılıç Çakmak, E., Akgün, Ö.E., Karadeniz, Ş., \& Demirel, F. (2012). Bilimsel araştırma yöntemleri (11. bask1). Ankara: Pegem Akademi.

Demirel, Ö. (2015). Kuramdan uygulamaya eğitimde program geliştirme. Ankara: Pegem Yayınc1lik.

Demirtaş, A. A. (2019). Sosyal bilgiler ögretmen adaylarının eleştirel düşünme eğilim düzeyleri (Yayımlanmamış yüksek lisans tezi). Kastamonu Üniversitesi Sosyal Bilimler Enstitüsü, Kastamonu.

Eldeleklioğlu, J., \& Özkılıç, R. (2008). Eleştirel düşünme eğitiminin pdr öğrencilerinin eleştirel düşünme becerilerine etkisi. Türk Psikolojik Danışma ve Rehberlik Dergisi, 3(29), 2536.

Ennis, R. H. (1985). Goals for a critical thinking curriculum. Costa, A. L. (Ed.), Developing minds: A resource book for teaching thinking (pp. 68-72). Virginia: ASCD

Erden, Y. (2009). Öğretmenlerin eleştirel düşünme eğilimlerinin mesleki özellikler açısından karşılaştırılması (Yayımlanmamış yüksek lisans tezi). Ankara Üniversitesi Eğitim Bilimleri Enstitüsü, Ankara.

Ersoy, E., \& Başer, N. (2011). İlköğretim ikinci kademede eleştirel düşünmenin yeri. Adnan Menderes Üniversitesi Ĕ̈itim Fakültesi Ĕ̈itim Bilimleri Dergisi, 2(1), 1-10.

Ertaş, H. (2012). Okul dışı etkinliklerle desteklenen eleştirel düşünme öğretiminin eleştirel düşünme eğilimine ve fizik dersine yönelik tutuma etkisi (Yayımlanmamış doktora tezi). Hacettepe Üniversitesi Fen Bilimleri Enstitüsü, Ankara.

Ertürk, S. (2016). Eğitimde program geliştirme (2. basım). Ankara: Edge Akademi Yayıncılık.

Erüs, E. E. (2007). Analitik geometri dersinde eleştirel düşünme becerilerine dayalı ögretimin ögrenci erişi düzeyi ve kalıcılığa etkisi (Yayımlanmamış yüksek lisans tezi). Hacettepe Üniversitesi Sosyal Bilimler Enstitüsü, Ankara.

Facione, N., \& Facione, P.A. (1996). Assessment design issues for evaluating critical thinking in Nursing. Holistic Nursing Practice, 10, 41-53.

Fraenkel, J. R., \& Wallen, N. E. (2006). How to design and evaluate research in education. Boston: McGraw-Hill.

Galloway, A. (2005). Non-probability sampling. In: Kemph-Leonar, K. (Ed.). Encyclopedia of social measurement, 859-864. New York: Elsevier. https://doi.org/10.1016/b0-12369398-5/00382-0

Gelen, İ. (1999). İlköğretim okulları 4.sinıf öğretmenlerinin sosyal bilgiler dersinde düşünme becerilerini kazandırma yeterliklerinin değerlendirilmesi (Yayımlanmamış yüksek lisans tezi). Çukurova Üniversitesi Sosyal Bilimler Enstitüsü, Adana.

Göbel, Ş. D. (2013). Sinıf ögrretmenlerinin eleştirel düşünme becerisi ögretimi yeterlilikleri ve uygulamaları (Yayımlanmamış yüksek lisans tezi). Sakarya Üniversitesi Eğitim Bilimleri Enstitüsü, Sakarya.

Gündüz, M. (2017). The impact of critical thinking based instruction on Turkish efl students' critical thinking disposition level, critical readind self-efficacy level, English writing performance and opinion on critical thinking (Yayımlanmamış yüksek lisans tezi). Bahçeşehir Üniversitesi Eğitim Bilimleri Enstitüsü, İstanbul.

Güner, C. (2015). The effects of critical-thinking based instruction on pre-service efl teachers' critical thinking disposition level, English reading self-efficacy level, and English writing performance (Yayımlanmamış yüksek lisans tezi). Marmara Üniversitesi Eğitim Bilimleri Enstitüsü, İstanbul. 
Harari, Y. N. (2018). 21 Lessons for the 21st Century. New York, NY: Spiegel and Grau.

Hayırsever, F., \& Oğuz, E. (2017). Öğretmen adaylarının eğitim inançlarının eleştirel düşünme eğilimlerine etkisi. Abant İzzet Baysal Üniversitesi Eğitim Fakültesi Dergisi, 17(2), 757778.

Hayran, İ. (2000). İlköğretim öğretmenlerinin düşünme beceri ve işlemlerine ilişkin görüşleri (Yayımlanmamış yüksek lisans tezi). Afyon Kocatepe Üniversitesi, Sosyal Bilimler Enstitüsü, Afyon.

Hirose, S. (1992). Critical thinking in community colleges. ERIC Digest. (ERIC Identifier: ED348128. https://files.eric.ed.gov/fulltext/ED348128.pdf adresinden 20 Mart 2019'da alınmıştır.

Kandemir, M.A. (2017). Sınıf ve ilköğretim matematik öğretmen adaylarının eleştirel düşünme eğilim düzeylerinin bazı değişkenlere göre incelenmesi. Turkish Studies, 12(6), 453474.

Kanik, F. (2010). Öğretmenlerin eleştirel düşünme anlayışlarının ve 7. sınıf düzeyinde eleştirel düşünmeyi geliştirmeye iliş̧kin uygulamalarının değerlendirilmesi (Yayımlanmamış doktora tezi). Orta Doğu Teknik Üniversitesi Sosyal Bilimler Enstitüsü, Ankara.

Karadeniz, A. (2006). Liselerde eleştirel düşünme eğitimi (Yayımlanmamış yüksek lisans tezi). Gazi Üniversitesi Eğitim Bilimleri Enstitüsü, Ankara.

Karalı, Y. (2012). Eğitim fakültesi öğrencilerinin eleştirel düşünme eğilimleri (Yayımlanmamış yüksek lisans tezi). İnönü Üniversitesi Eğitim Bilimleri Enstitüsü, Malatya.

Karasar, N. (2012). Bilimsel araştırma yöntemleri. (24.bask1), Ankara: Nobel Yayıncılık.

Korkmaz, Ö. (2009). Eğitim fakültelerinin öğrencilerin eleştirel düşünme eğilim ve düzeylerine etkisi. Türk Ĕ̈itim Bilimleri Dergisi, 7(4), 879-902.

Kural, V. (2018). Beden eğitimi ve spor ögretmenliği bölümü ögrencilerinin eleştirel düşünme eğilimlerinin akademik öz yeterliklerinin bazı değişkenlere göre incelenmesi (Yayımlanmamış yüksek lisans tezi). Bartın Üniversitesi Eğitim Bilimleri Enstitüsü, Bartın.

Kurnaz, A. (2007). İlköğretim beşinci sınıf sosyal bilgiler dersinde beceri ve içerik temelli eleştirel düsünme ögretiminin ögrencilerin eleştirel düsünme becerileri, erişi ve tutumlarına etkisi (Yayımlanmamış doktora tezi). Selçuk Üniversitesi Sosyal Bilimler Enstitüsü, Konya.

Küçük, G. (2007). Aday öğretmenlerin eleştirel düşünme eğilimleri ile duygusal zeka düzeyleri arasındaki iliş̧ki (Yayımlanmamış yüksek lisans tezi). Abant İzzet Baysal Üniversitesi Sosyal Bilimler Enstitüsü, Bolu.

Kürüm, D. (2002). Öğretmen adaylarının eleştirel düşünme gücü (Yayımlanmamış yüksek lisans tezi). Anadolu Üniversitesi Eğitim Bilimleri Enstitüsü, Eskişehir.

Melek, Ç. (2011). Bir ilköğretim matematik öğretmeninin etkinlik seçimlerine ilişsin pedagojik akıl yürütme süreçleri (Yayımlanmamış doktora tezi). Orta Doğu Teknik Üniversitesi Fen Bilimleri Enstitüsü, Ankara.

Nosich, G. M. (2012). Eleştirel düşünme rehberi (Çev: Birsel Aybek). Ankara: Anı Yayıncılık.

Özden, S. (2019). Ortaokul öğretmenlerinin yaşam boyu öğrenme ile eleştirel düşünme eğilimlerinin incelenmesi (Yayımlanmamış doktora tezi). İnönü Üniversitesi Eğitim Bilimleri Enstitüsü, Malatya. 
Özsevgeç, T., \& Altun, E. (2015). Fen bilimleri öğretmenlerinin eleştirel düşünmeye yönelik görüşlerinin belirlenmesi. Dicle Üniversitesi Ziya Gökalp Eğitim Fakültesi Dergisi, 24, 66-95.

Özüberk, D. (2002). Feuerstein'ın aracılı zenginleştirme programı temel alınarak hazırlanan programin lise birinci sinıf ögrencilerinin eleştirel düşünme becerilerine etkisi (Yayımlanmamış yüksek lisans tezi). Çukurova Üniversitesi Sosyal Bilimler Enstitüsü, Adana.

Özyurt, M., \& Bezirgan, G. (2019). Sınıf öğretmenlerinin eleştirel düşünme becerisini geliştirmeye yönelik yöntem ve teknikleri kullanım sıklıklarının incelenmesi. Erzincan Üniversitesi Ë̆itim Fakültesi Dergisi 21(1), 270-287.

Pellegrino, J. W., \& Hilton, M. L. (2012). Education for life and work: Developing transferable knowledge and skills in the $21^{\text {st }}$ century. Washington, DC: The National Academies Press.

Peter, E. E. (2012). Critical thinking: Essence for teaching mathematics and mathematics problem solving skills. African Journal of Mathematics and Computer Science Research, 5(3), 39-43.

Reed, J. H., \& Kromrey, J. D. (2001). Teaching critical thinking in a community college history course: Empirical evidence from infusing Paul's model. College Student Journal, 35(2), 201.

Seferoğlu, S. S., \& Akbıyık, C. (2006). Eleştirel düşünme ve öğretimi. Hacettepe Üniversitesi Eğitim Fakültesi Dergisi, 30(30), 193-200.

Schreglmann, S. (2011). Konu temelli eleştirel düşünme ögrretiminin öğretmen adaylarının akademik başarı, eleştirel düşünme eğilimine ve düzeyine olan etkisi (Yayımlanmamış yüksek lisans tezi). Çukurova Üniversitesi Sosyal Bilimler Enstitüsü, Adana.

Semerci, N. (2016). Eleştirel düşünme eğilim ölçeğinin geliştirilmesi: Geçerlik ve güvenirlik revize çalışmas1. Turkish Studies, 11(9), 725-740.

Sternberg, R.J. (1999). The mature of cognition. Boston: MIT Press.

Sofuoğlu, S. (2019). Müze eğitiminin eleştirel düşünme eğilimine ve problem çözeme becerisine etkisi (Yayımlanmamış yüksek lisans tezi). İstanbul Üniversitesi Lisansüstü Eğitim Enstitüsü, İstanbul.

Söğüt, B. Ö. (2009). Öğrencilerin ve matematik ögrretmenlerinin eleştirel düşünme becerilerini kazanmaya yönelik görüşleri (Yayımlanmamış yüksek lisans tezi). Afyon Kocatepe Üniversitesi Sosyal Bilimler Enstitüsü, Afyon.

Sönmez, V. (2015). Program geliştirmede öğretmen el kitabı (18. basım) Ankara: Anı Yayıncilik.

Şahin, A. (2014). The relationship between english language teachers' critical thinking dispositions levels and their levels of utilizing critical thinking strategies (Yayımlanmamış yüksek lisans tezi). Çağ Üniversitesi, Sosyal Bilimler Enstitüsü, Mersin.

Şahinel, S. (2001). Eleştirel düşünme becerileri ile tümleşik dil becerilerinin gelişstirilmesi (Yayımlanmamış yüksek lisans tezi). Hacettepe Üniversitesi Sosyal Bilimler Enstitüsü, Ankara.

Şahinel, S. (2007). Eleştirel düşünme. Ankara: Pegem Yayıncılık. 
Şengül, C., \& Üstündağ, T. (2009). Fizik öğretmenlerinin eleştirel düşünme eğilimi düzeyleri ve düzenledikleri etkinliklerde eleştirel düşünmenin yeri. Hacettepe Üniversitesi Eğitim Fakültesi Dergisi 36, 237-248.

Tishman, S., Jay E., \& Perkins, D. N. (1992). Teaching thinking dispositions: From transmission to enculturation. Theory Into Practice, 32(3), 147-153.

Tok, E., \& Sevinç, M. (2010). Düşünme becerileri eğitiminin eleştirel düşünme ve problem çözme becerilerine etkisi. Pamukkale Üniversitesi Eğitim Fakültesi Dergisi, 27(27), 6782.

Varış, F. (1997). Eğitimde program geliştirme teoriler-teknikler. Ankara: Alkım Yayınları.

Wenglinsky, H. (2004). Facts of critical thinking skills? What NAEP results say. Educational Leadership, 62(1), 32.

World Economic Forum (2018). The future of jobs report 2018. Geneva: World Economic Forum. http://hdl.voced.edu.au/10707/465072 adresinden 19 Aralık 2019'da alınmıştır.

Yağc1, R. (2008). Sosyal bilgiler öğretiminde eleştirel düşünme: İlköğretim 5. sinıf sosyal bilgiler öğretiminde, öğretmenlerin eleştirel düşünme becerilerini geliş̧irmek için uyguladıkları etkinliklerin değerlendirilmesi (Yayımlanmamış yüksek lisans tezi). Çukurova Üniversitesi Sosyal Bilimler Enstitüsü, Adana.

Yang, T. C. (2012). Cultivating critical thinkers: Exploring transfer of learning from pre-service teacher training to classroom practice. Teaching and Teacher Education, 28, 11161130 .

Yıldırım, Ç. A. (2005). Türkçe ve Türk dili ve edebiyatı ögrretmenlerinin eleştirel düşünme becerilerinin incelenmesi (Yayımlanmamıș yüksek lisans tezi). Zonguldak Karaelmas Üniversitesi, Sosyal Bilimler Enstitüsü, Zonguldak.

\section{EXTENDED SUMMARY}

\section{Introduction}

The rapidly developing science and technology all over the world has carried the expectations from individuals and institutions to different dimensions. The conditions in the world and the changes over time also change the skills expected from people. These expectations have changed the view towards educational institutions. Depending on this change, the important thing in the education system is not the transfer of information, but the students' ability to make sense of the information and distinguish between the important and the unimportant (Harari, 2018). Different education systems have emphasized the importance of students acquiring the skills necessary to participate in an ever-changing and increasingly complex world (Pellegrino $\&$ Hilton, 2012). For this reason, thinking skills have an important place in the world and in education programs. Looking at the skills that are called 21 st century skills that should be possessed today, it is seen that critical thinking skills are among these skills (World Economic Forum, 2018).

Critical thinking is a set of mental processes, strategies and methods used in problem solving (Sternberg, 1999). In critical thinking, the person decides what is right or wrong by making sense of the information presented (Ennis, 1985). According to Nosich (2012), critical thinking deals with asking, examining, solving questions by placing them on a logical ground and believing the results.

Critical thinking disposition is necessary for critical thinking skills and is a circular process that enables a person to make a decision about any subject (Facione \& Facione, 1996). Features such 
as searching for the true expression of a claim or problem, searching for reasons related to the claim, trying to find reliable sources for information, approaching the event with a holistic perspective, not deviating from the main problem, producing alternatives, being open-minded, showing the responsibility to take a decision when there are sufficient reasons for the solution of the problem. are the main indicators of critical thinking disposition (Ennis, 1985: 68).

Teachers with critical thinking skills and inclinations should also have sufficient equipment to teach critical thinking. In the teaching of critical thinking skills, first of all, the concept of critical thinking should be defined very well and the necessity of critical thinking should be emphasized to students (Şahinel, 2007: 52). Because the concept of critical thinking, which has not been adequately expressed and clarified, will not go beyond an ordinary teaching or activity in the eyes of students. According to Hirose (1992), students should go beyond memorizing a fact and be encouraged to adapt this fact to a particular field of thought.

In order to gain critical thinking skills, it is important for teachers to organize their learning environments accordingly, and to move from the role of the person who conveys certain information to the students and the person who encourages flexible thinking and questioning. In addition, encouraging students to ask more open-ended questions, to think, analyze and conceptualize problems is important in the process of gaining critical thinking skills.

Critical thinking activities in mathematics lessons will make students more successful than the effects of basic skills. Because gaining high-level thinking skills to students at an early age will increase the motivation of students at the point of learning the basic operational steps (Wenglinsky, 2004). For this reason, the aim of mathematics teachers who want to gain critical thinking skills in their classrooms should be to think of their students as information users, not information buyers. Students will develop their critical thinking skills in math learning environments that actively involve students in knowledge research and the application of the acquired knowledge, and thus students will gain high-level thinking skills. In addition, critical thinking skills can be developed by encouraging students throughout the process and modeling their thinking behaviors in mathematics lessons (Peter, 2012).

\section{Purpose}

The starting point of the study was to reveal the critical thinking tendency levels of middle school mathematics teachers, their in-class application levels regarding teaching critical thinking, and the level of the relationship between these variables. For this reason, the study aims to reveal how the perceptions of critical thinking tendency of middle school mathematics teachers affect their perceptions of teaching practices that develop critical thinking.

\section{Method}

In the research, the relational screening model, one of the quantitative research methods, was used. The research sample consists of 381 middle school mathematics teachers working in the provinces of Düzce, Karabük, Kastamonu, and Çorum, who was selected with the convenience sampling technique from non-random sampling methods. Critical Thinking Tendency Scale and Critical Thinking Instruction Application Scale were used as data collection scales in the study. The analysis of the data obtained from the scales was carried out in a computer environment. According to the normality analysis, it was seen that the data showed a normal distribution. Accordingly, independent samples $t$-test and one-way analysis of variance were used to examine the effects of independent variables. In addition, Pearson correlation analysis and multiple linear regression analysis were used to determine the relationship between teachers' critical thinking tendency and application levels. 


\section{Findings and Interpretation}

According to these score averages, the critical thinking tendencies of middle school mathematics teachers are seen at a very high level for the whole scale and all sub-dimensions. There is no significant difference by gender in the critical thinking tendency of teachers on the whole scale and in all sub-dimensions. Accordingly, it can be said that gender has no effect on critical thinking tendencies. While there was no significant difference in the critical thinking tendencies of teachers according to seniority in the scale total, a significant difference was found in the metacognition sub-dimension in favor of teachers with seniority of 16 years or more compared to teachers with seniority of 1-5 years. Accordingly, it can be said that the higher the seniority, the higher the metacognitive tendency. However, no significant difference was found in other sub-dimensions. According to the in-service training variable, a significant difference was observed in the critical thinking tendencies of teachers in favor of those who received education on the whole scale and in all sub-dimensions. Accordingly, it can be said that getting training in critical thinking increases teachers' critical thinking tendencies.

\section{Discussion and Conclusion}

Within the scope of the study, it was concluded that teachers' perceptions of critical thinking tendencies were at a very high level. In the study, no significant difference was found in the teachers' critical thinking tendency perceptions according to gender variables. While there was no significant difference for the total scale score according to the seniority variable, it was concluded that there was a significant difference in metacognitive tendency in favor of teachers with seniority of 16 years or more. On the other hand, a significant difference was found in favor of the teachers who received training according to the in-service training variable.

In the study, it was concluded that teachers' perceptions of applying critical thinking teaching were very high. In the study, no significant difference was found in critical thinking practices according to the gender variable, but a significant difference was found in favor of male teachers in the sub-dimension of the teaching environment. According to the seniority variable, a significant difference was found in the teachers' perceptions of applying critical thinking in the scale total and the teacher qualifications sub-dimension in favor of teachers with seniority of 16 years or more compared to teachers with 11-15 years of seniority. According to the in-service training variable, a significant difference was found in the perceptions of applying critical thinking in the total of the scales and in favor of the teachers trained in all sub-dimensions.

In the study, it was determined that there is a moderate, positive, and significant relationship between the teachers' critical thinking tendency perceptions and their perceptions of teaching critical thinking. In addition, according to the regression analysis, it was determined that critical thinking tendency predicted $40 \%$ of critical thinking teaching practices, and it was concluded that perseverance, open-mindedness, and metacognitive tendencies were significant predictors of critical thinking teaching practices.

\section{Etik Kurul İzin:}

Yapılan bu çalışmada "Yükseköğretim Kurumları Bilimsel Araştırma ve Yayın Etiği Yönergesi" kapsamında uyulması belirtilen tüm kurallara uyulmuştur. Bu çalışma için etik kurul izni Düzce Üniversitesi Bilimsel Araştırma ve Yayın Etik Kurulu'nun 16/05/2019 tarihli ve 2019/46 numaralı kararı ile alınmıştır. 